\title{
Effects of Interaction Between Slurry, Soil Conditioners and Mineral Fertilizers on the Content of Fibre Fractions in Lolium multiflorum (Lam)
}

\author{
Beata Wiśniewska-Kadżajan ${ }^{1 *}$, Kazimierz Jankowski \\ 1 Siedlce University of Natural Sciences and Humanities, Faculty of Agrobioengineering and Animal Husbandry \\ ul. Prusa 14, 08 - 110 Siedlce, Poland \\ * Corresponding author's e-mail: beata.wisniewska-kadzajan@uph.edu.pl
}

\begin{abstract}
The research was aimed at assessing the effect of complementary use of slurry with soil conditioners and the NPK fertilizers on the content of the crude fibre fractions in the biomass of Lolium multiflorum. The studies were conducted on the basis of a two-year (2016-2017) field experiment established in three replications in a completely randomized design. The impact of slurry and its interaction with soil conditioners and the NPK fertilizers was tested on the Dukat variety of Lolium multiflorum forage grass. The results demonstrated that there was no significant effect of the treatments on the content of the crude fibre and its fraction in the grass. However, the ADF and ADL fibre content varied significantly across the growing seasons. In the same growing season, the crude fibre content as well as the content of the ADL fraction varied across three Lolium multiflorum harvests.
\end{abstract}

Keywords: fiber fraction; natural fertilization, forage grasses

\section{INTRODUCTION}

The characteristic feature of roughage plants is their high content of the crude fibre, so-called 'structural carbohydrates', and the soluble fibre (Kukułka and Kozłowski 2004). The following fractions of the crude fibre are distinguished: neutral detergent fibre (NDF), acid detergent (ADF) and acid detergent lignin (ADL). The NDF fraction consists of cellulose, hemicellulose and lignin, ADF consists of cellulose and lignin without tannins, while ADL of lignin, cutin and ash (Brzóska and Śliwiński 2011).

Each of the fibre fractions affects other parameters of forage. According to Luczak and Rogalski (2004) the minimum crude fibre content should range from 10 to $15 \%$ DM. However, to ensure high digestibility of nutrients and the proper energy value, the crude fibre levels in the forage should not exceed 28-30\% DM. According to Brzóska and Śliwiński (2011), the increased NDF content lowers the intake of animal feed, while its larger ADF amounts negatively affect digestibility. Therefore, low ADF content is desirable as it means a higher net energy concentration. However, excessive level of NDF negatively affects the energy intake.

The research was aimed at assessing the content of individual crude fibre fractions in the biomass of Lolium multiflorum treated with the slurry applied together with soil conditioners or with NPK fertilizers.

\section{MATERIAL AND METHODS}

The research was carried out on the basis of a two-year (2016-2017) field experiment established at the experimental facility of University of Natural and Sciences and Humanities in Siedlce $\left(52^{\circ} 10^{\prime} \mathrm{N}, 22^{\circ} 17^{\prime} \mathrm{E}\right)$, with three replications and a completely randomized design. The area of an experimental plot was $4.5 \mathrm{~m}^{2}$ $(1.5 \times 3.0 \mathrm{~m})$.

The main experimental factor tested in the research was slurry used separately and 
supplemented with the NPK mineral fertilizers or soil conditioners with the commercial names of UGmax and Humus Active. The following research units were set up: (1) control (no treatment); (2) slurry; (3) slurry + UGmax; (4) slurry + Humus Active; (5) slurry + NPK.

The effect of slurry, soil conditioners, and mineral fertilisers was tested on the forage grass of the Lolium multiflorum species of the Dukat variety. It was planted in autumn 2015 at the sowing standard of $18 \mathrm{~kg} \mathrm{ha}^{-1}$. The slurry from dairy cows was used as natural fertiliser. It was applied each year in a total dose of $30 \mathrm{~m}^{3}$ $\mathrm{ha}^{-1}$ divided into three equal parts used before each growth cycle. The dry matter concentration of the slurry was $10 \%$, with a narrow ratio of $\mathrm{C}: \mathrm{N}(8: 1)$, while the concentration of selected macronutrients was as follows $\left(\mathrm{g} \mathrm{kg}^{-1} \mathrm{DM}\right)$ : $\mathrm{N}-33.0, \mathrm{P}_{2} \mathrm{O}_{5}-16.0, \mathrm{~K}_{2} \mathrm{O}-16, \mathrm{MgO}-10.0$ and $\mathrm{Ca}-21.0$.

Soil conditioners were applied annually before the growing season at the doses recommended by the manufacturer, i.e. UGmax $-0.6 \mathrm{dm} \mathrm{ha}^{-1}$, while Humus Active-50 dm ha ${ }^{-1}$. Their chemical composition is presented in Table 1.

Mineral nitrogen was used in the form of ammonium nitrate $\left(\mathrm{NH}_{4} \mathrm{NO}_{3}\right)$, phosphorus in the form of triple granular superphosphate $\left(\mathrm{Ca}\left(\mathrm{H}_{2} \mathrm{PO}_{4}\right)_{2}\right)$ and potassium in the form of potassium salt $(\mathrm{KCl})$ in the following doses: $\mathrm{N}-100, \mathrm{P}\left(\mathrm{P}_{2} \mathrm{O}_{5}\right)-80$, $\mathrm{K}\left(\mathrm{K}_{2} \mathrm{O}\right)-120 \mathrm{~kg} \mathrm{ha}^{-1}$.

Phosphorus was applied once a year before the first growth cycle, whereas the nitrogen and potassium doses were divided into three equal parts: the first before the start of vegetation, the second and third before the second and third growth cycles. The experiment was set up on the soil with the granulometric composition of loamy sand, the order of anthropogenic soils, the type of culture earth soil, and the subtype of hortisole (PTG 2011).

According to the chemical analysis of the soil carbon concentration in organic compounds $\left(\mathrm{C}_{\text {org }}\right)$ was $14.50 \mathrm{~g} \mathrm{~kg}^{-1} \mathrm{DM}$, with total nitrogen of $1.36 \mathrm{~g} \mathrm{~kg}^{-1} \mathrm{DM}$. The ratio of $\mathrm{C}: \mathrm{N}$ was 10.6:1, and the $\mathrm{pH}$ value was 6.7. The concentration of the absorbable forms of phosphorus (170.00 mg kg-1 DM) and magnesium (84.00 mg kg-1 DM) was high, with moderate concentration of potassium (114.00 $\left.\mathrm{mg} \mathrm{kg}^{-1} \mathrm{DM}\right)$.

The hydrothermal conditions were determined on the basis of the meteorological data from the Hydrological and Meteorological Station in Siedlce. In order to measure the temporal variability of weather conditions and their effects on the plant growth and development Sielianinov's hydrothermal coefficient (Table 2) was determined (Bac et al. 1993). It was calculated using the monthly sum of atmospheric precipitation $(\mathrm{P})$ and the monthly sum of average daily air temperatures $(\Sigma \mathrm{t})$, applying the formula: $\mathrm{K}=\mathrm{P} / 0.1 \Sigma \mathrm{t}$ (Skowera and Puła 2004).

In the first year (2016) the optimum thermal and humidity conditions occurred only in the month of September, with severely wet May, while June, July, and August, i.e. the most

Table 1. Composition of soil conditioners

\begin{tabular}{|c|c|c|c|c|c|c|c|c|c|c|c|}
\hline \multirow{2}{*}{$\begin{array}{c}\text { Soil } \\
\text { conditioner }\end{array}$} & \multicolumn{5}{|c|}{ Macronutrients $\left(\mathrm{g} \mathrm{kg}^{-1}\right)$} & \multicolumn{4}{c|}{$\begin{array}{c}\text { Micronutrients } \\
\left(\mathrm{mg} \mathrm{kg}^{-1}\right)\end{array}$} & \multicolumn{2}{c|}{ Microorganism and others } \\
\cline { 2 - 11 } & $\mathrm{N}$ & $\mathrm{P}$ & $\mathrm{K}$ & $\mathrm{Ca}$ & $\mathrm{Mg}$ & $\mathrm{Na}$ & $\mathrm{Mn}$ & $\mathrm{Fe}$ & $\mathrm{Zn}$ & $\mathrm{Cu}$ & \\
\hline UGmax & 1.2 & 0.2 & 2.9 & - & 0.1 & 0.2 & 0.3 & - & - & $-\begin{array}{l}\text { Lactic acid bacteria, photosynthetic } \\
\text { bacteria, Azotobacter, Pseudomonas, yeast, } \\
\text { actinomycetes }\end{array}$ \\
\hline Humus Active & 0.2 & 1.3 & 4.6 & 3.0 & 0.5 & - & 15 & 500 & 3 & 1 & $\begin{array}{l}\text { Permanent active humus with beneficial } \\
\text { microorganisms }\end{array}$ \\
\hline
\end{tabular}

Table 2. The value of Sielianinov's hydrothermal coefficient $(\mathrm{K})$ in the growing seasons.

\begin{tabular}{|c|c|c|c|c|c|c|c|}
\hline \multirow{2}{*}{ Year } & \multicolumn{7}{|c|}{ Month } \\
\cline { 2 - 8 } & April & May & June & July & August & September & October \\
\hline 2015 & $1.36(\mathrm{o})$ & $1.87(\mathrm{mw})$ & $1.64(\mathrm{mw})$ & $0.59(\mathrm{sd})$ & $1.92(\mathrm{mw})$ & $0.64(\mathrm{sd})$ & $0.12(\mathrm{ed})$ \\
\hline 2016 & $1.22(\mathrm{md})$ & $2.63(\mathrm{sw})$ & $0.87(\mathrm{~d})$ & $1.08(\mathrm{md})$ & $0.18(\mathrm{ed})$ & $1.46(\mathrm{o})$ & $1.94(\mathrm{mw})$ \\
\hline 2017 & $2.88(\mathrm{sw})$ & $1.15(\mathrm{md})$ & $1.08(\mathrm{md})$ & $0.45(\mathrm{sd})$ & $0.96(\mathrm{~d})$ & $1.92(\mathrm{mw})$ & $1.90(\mathrm{mw})$ \\
\hline
\end{tabular}

$\mathrm{K} \leq 0.4$ extremely dry (ed), $0.4<\mathrm{K} \leq 0.7$ severely dry (sd), $0.7<\mathrm{K} \leq 1.0$ dry (d), $1.0<\mathrm{K} \leq 1.3$ moderately dry (md), $1.3<\mathrm{K} \leq 1.6$ optimal (o), $1.6<\mathrm{K} \leq 2.0$ moderately wet (mw), $2.0<\mathrm{K} \leq 2.5$ wet (w), $2.5<\mathrm{K} \leq 3.0$ severely wet (sw), K $>3.0$ extremely wet (ew) 
important months for plant growth and development, were dry, moderately dry, and extremely dry. In the second year of the experiment, the period from May to August ranged from moderately dry to severely dry, and the optimum conditions were not recorded during any month of the growing season.

During the two-year experiment, three harvests of grass were collected in each growing season. Immediately after each harvest, the fresh matter was weighed, and a sample of $0.5 \mathrm{~kg}$ was collected to determine the yield of dry matter and to perform the chemical analyses. The crude fibre and its fraction (NDF, ADF and ADL) content was measured with the near-infrared spectroscopy method (LSDS), using the LSDFlex $\mathrm{N}-500$ with the ready-to-use INGOT calibration for dry forage. The method is described in detail in the Polish standard of PN-EN ISO 12099:2010 and in the literature (Burns et al. 2010; Reddersen et al. 2012).

The analysis of variance for a three-factor experiment was performed to process the results statistically. The significance of the effect of various treatments on the value of the parameters was checked with the Fisher-Snedecor F test, and the value of $\mathrm{LSD}_{0.05}$ was verified with
Tukey's test. The Statistica 6.0-2001 software package was used for calculations.

\section{RESULTS}

The crude fibre content (Table 3) in Lolium multiflorum significantly varied across harvests. The largest content of the crude fibre with $295.6 \mathrm{~g} \mathrm{~kg}^{-1} \mathrm{DM}$ in the first year and $283.3 \mathrm{~g} \mathrm{~kg}^{-1} \mathrm{DM}$ in the second was recorded on the plot with the slurry applied together with the Humus Active soil conditioner, while the smallest was observed in the first year in the plants treated with slurry alone, with $269.6 \mathrm{~g} \mathrm{~kg}^{-1} \mathrm{DM}$ , and in the second year on the control plot, with $265.1 \mathrm{~g} \mathrm{~kg}^{-1} \mathrm{DM}$. The content of the crude fibre in Lolium multiflorum treated with the slurry applied together with soil conditioners was greater than that in the plants treated with the slurry on its own and the slurry combined with the NPK fertilizers. The largest and statistically significant crude fibre content across the growing seasons and harvests was recorded in the third-cut grass (293.9 $\left.\mathrm{g} \mathrm{kg}^{-1} \mathrm{DM}\right)$, while it was the lowest (260.2 $\left.\mathrm{g} \mathrm{kg}^{-1} \mathrm{DM}\right)$ in the grass of the first harvest.

Table 3. The effect of treatments on crude fibre content in Lolium multiflorum dry matter across harvests and growing seasons $\left(\mathrm{g} \mathrm{kg}^{-1}\right)$.

\begin{tabular}{|c|c|c|c|c|c|c|c|}
\hline \multirow{2}{*}{$\begin{array}{l}\text { Growing } \\
\text { season } \\
\text { (B) }\end{array}$} & \multirow{2}{*}{$\begin{array}{l}\text { Harvest } \\
\text { (C) }\end{array}$} & \multicolumn{5}{|c|}{ Treatments $(\mathrm{A})$} & \multirow{2}{*}{ Means } \\
\hline & & $\mathrm{O}$ & *S & S+UGmax & $\mathrm{S}+\mathrm{HA}$ & $S+N P K$ & \\
\hline \multirow{4}{*}{2016} & I & 268.4 & 254.6 & 268.7 & 279.5 & 249.3 & 264.1 \\
\hline & II & 287.6 & 270.4 & 299.9 & 302.9 & 288.7 & 289.9 \\
\hline & III & 299.8 & 284.6 & 300.4 & 304.3 & 312.7 & 300.4 \\
\hline & Means & 285.3 & 269.9 & 289.7 & 295.6 & 283.6 & 284.8 \\
\hline \multirow{4}{*}{2017} & 1 & 224.7 & 255.8 & 265.4 & 267.6 & 267.3 & 256.2 \\
\hline & II & 275.2 & 296.1 & 289.6 & 290.4 & 289.4 & 288.1 \\
\hline & III & 295.3 & 290.3 & 294.5 & 292.0 & 264.9 & 287.4 \\
\hline & Means & 265.1 & 280.7 & 283.2 & 283.3 & 273.9 & 277.2 \\
\hline \multicolumn{2}{|c|}{$\begin{array}{c}\text { Means across growing } \\
\text { seasons }\end{array}$} & 275.2 & 275.3 & 286.4 & 289.5 & 278.8 & 281.0 \\
\hline \multicolumn{8}{|c|}{ Means across harvests } \\
\hline \multicolumn{2}{|c|}{1} & 246.6 & 255.2 & 267.1 & 273.6 & 258.3 & 260.2 \\
\hline \multicolumn{2}{|c|}{ II } & 281.4 & 283.3 & 294.8 & 296.7 & 289.1 & 289.1 \\
\hline \multicolumn{2}{|c|}{ III } & 297.6 & 287.5 & 297.5 & 298.2 & 288.8 & 293.9 \\
\hline $\mathrm{O}_{0.05}$ for: & $\begin{array}{l}\mathrm{A}=\mathrm{NS}^{* *} \\
\mathrm{~A} / \mathrm{B}=\mathrm{NS} \\
\mathrm{C} / \mathrm{A}=\mathrm{NS}\end{array}$ & $\begin{array}{l}\mathrm{B} / \mathrm{A}=\mathrm{NS} \\
\mathrm{B} / \mathrm{C}=\mathrm{NS}\end{array}$ & & \multicolumn{2}{|c|}{$\begin{array}{l}\mathrm{A} / \mathrm{C}=\mathrm{NS} \\
\mathrm{C} / \mathrm{B}=\mathrm{NS}\end{array}$} & & \\
\hline
\end{tabular}

*S - slurry; S +UGmax - slurry + biopreparation UGmax; S + HA - slurry + biopreparation Humus Active; S + NPK - slurry + mineral fertilizers NPK

** NS - not significiant 
Across the growing seasons, the largest but non-statistically significant content of neutral detergent fibre (539.4 $\mathrm{g} \mathrm{kg}^{-1} \mathrm{DM}$ ) was found in Lolium multiflorum treated with the slurry supplemented with the UGmax soil conditioner, with its lowest amounts $\left(514.6 \mathrm{~g} \mathrm{~kg}^{-1} \mathrm{DM}\right)$ in the control plants (Table 4).

The NDF content in Lolium multiflorum treated with slurry supplemented with soil conditioners or the NPK mineral fertilizers was higher than in the grass treated with slurry only. The highest amount of the NDF fibre across growing seasons and treatments was recorded in the grass of the second harvest (549.3 $\left.\mathrm{g} \mathrm{kg}^{-1} \mathrm{DM}\right)$ and the lowest in the third (523.6 $\left.\mathrm{g} \mathrm{kg}^{-1} \mathrm{DM}\right)$. The content of acid detergent fibre (Table 5) in the grass varied across the growing seasons. In the first growing season, the ADF fibre content, the average of the harvests, was $332.4 \mathrm{~g} \mathrm{~kg}^{-1} \mathrm{DM}$, with $349.4 \mathrm{~g} \mathrm{~kg}^{-1}$ $\mathrm{DM}$ in the second growing season.

The most ADF fibre in Lolium multiflorum across the growing seasons was recorded on the plot with the slurry supplemented with the NPK fertilisers (344.8 $\left.\mathrm{g} \mathrm{kg}^{-1} \mathrm{DM}\right)$, and the least in the grass treated with the slurry applied together with the Humus Active soil conditioner $\left(332.2 \mathrm{~g} \mathrm{~kg}^{-1}\right.$ DM). The addition of NPK fertilisers to the slurry resulted in a slightly higher increase in the ADF content than the application of the slurry on its own. The interactive effect of slurry and soil conditioners was not significantly different from the effect of the slurry applied on its own. The increase was higher in the plants treated with the slurry supplemented with the UGmax soil conditioner.

The most ADF fibre, the average for treatments and growing seasons, was recorded in the grass of the second harvest ( $\left.349.6 \mathrm{~g} \mathrm{~kg}^{-1} \mathrm{DM}\right)$, and the least in the third harvest (335.1 $\left.\mathrm{g} \mathrm{kg}^{-1} \mathrm{DM}\right)$. The content of the acid detergent lignin (ADL) in Lolium multiflorum (Table 6) was significantly differentiated across the growing seasons and harvests.

The interaction between the slurry and soil conditioners or the slurry and the NPK mineral fertilizers did not significantly affect the content of the ADL fraction in Lolium multiflorum. Significantly more of the ADL fraction was recorded in the second year $\left(40.9 \mathrm{~g} \mathrm{~kg}^{-1} \mathrm{DM}\right)$ than in the first $\left(38.1 \mathrm{~g} \mathrm{~kg}^{-1} \mathrm{DM}\right)$. Across the harvests, significantly more ADL fibre was found in the grass of the third cut $\left(40.4 \mathrm{~g} \mathrm{~kg}^{-1} \mathrm{DM}\right)$ than in the first one, in which it was the lowest $\left(38.3 \mathrm{~g} \mathrm{~kg}^{-1} \mathrm{DM}\right)$.

Table 4. The effect of treatments on neutral detergent fibre content in Lolium multiflorum dry matter across harvests and growing seasons $\left(\mathrm{g} \mathrm{kg}^{-1}\right)$

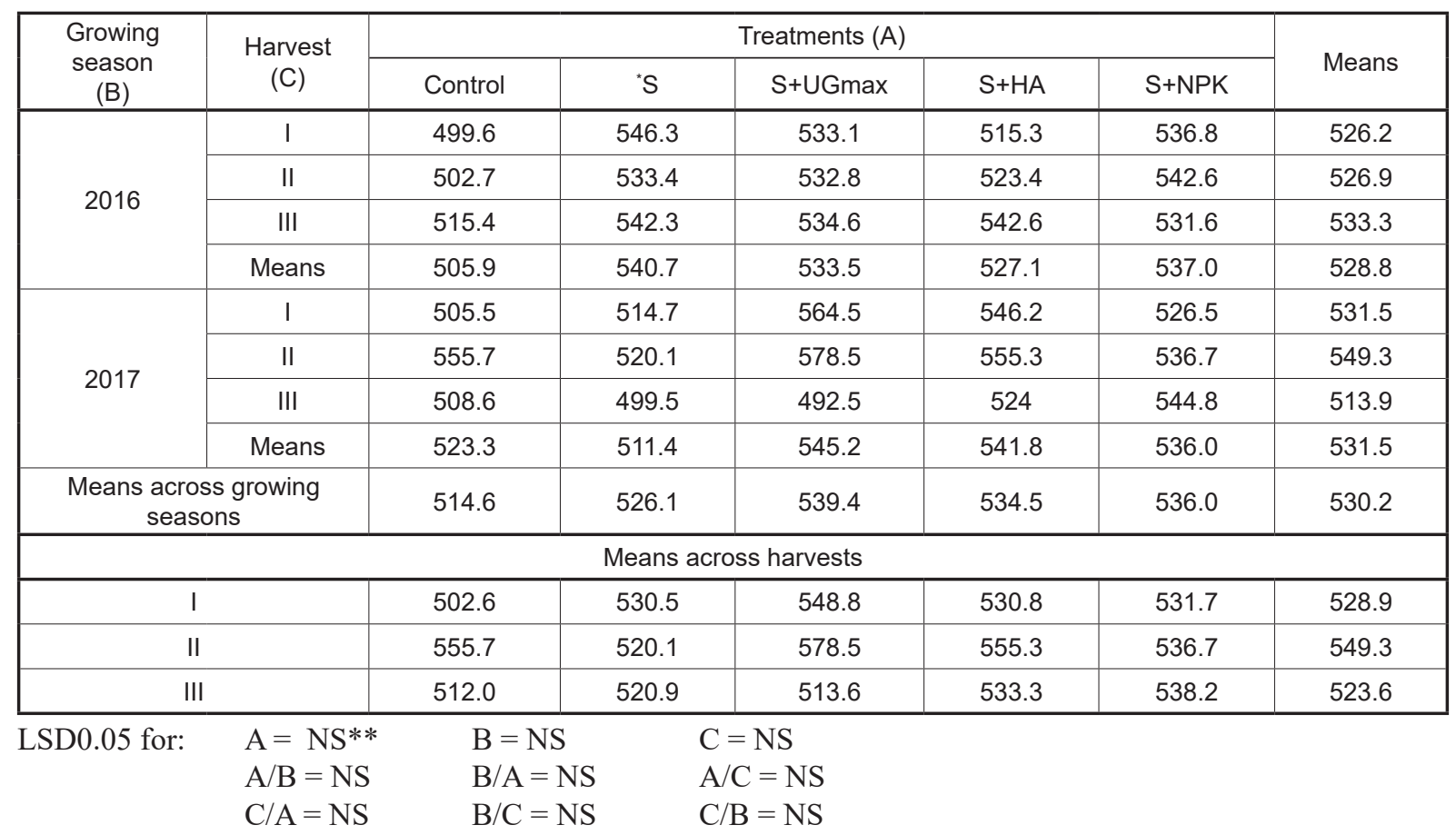

${ }^{*} \mathrm{~S}$ - slurry; S +UGmax - slurry + biopreparation UGmax; S + HA - slurry + biopreparation Humus Active; S + NPK - slurry + mineral fertilizers NPK

* NS - not significiant 
Table 5. The effect of treatments on acid detergent fibre content in Lolium multiflorum dry matter across harvests and growing seasons $\left(\mathrm{g} \mathrm{kg}^{-1}\right)$.

\begin{tabular}{|c|c|c|c|c|c|c|c|}
\hline \multirow{2}{*}{$\begin{array}{l}\text { Growing } \\
\text { season } \\
\text { (B) }\end{array}$} & \multirow{2}{*}{$\begin{array}{l}\text { Harvest } \\
\text { (C) }\end{array}$} & \multicolumn{5}{|c|}{ Treatments $(\mathrm{A})$} & \multirow{2}{*}{ Means } \\
\hline & & Control & $S$ & S+UGmax & $\mathrm{S}+\mathrm{HA}$ & S+NPK & \\
\hline \multirow{4}{*}{2016} & 1 & 335.6 & 326.1 & 328.2 & 326.4 & 325 & 328.3 \\
\hline & II & 349.4 & 351.9 & 320.5 & 320.0 & 385.1 & 345.4 \\
\hline & III & 352.1 & 354.1 & 298.1 & 298.7 & 314.6 & 323.52 \\
\hline & Means & 345.7 & 344.0 & 315.6 & 315.0 & 341.6 & 332.4 \\
\hline \multirow{4}{*}{2017} & 1 & 325.5 & 353.0 & 363.7 & 345.9 & 349.4 & 347.5 \\
\hline & II & 353.8 & 344.2 & 373.8 & 346.1 & 351.6 & 353.9 \\
\hline & III & 335.0 & 321.3 & 378.1 & 356.2 & 342.8 & 346.7 \\
\hline & Means & 338.1 & 339.5 & 371.9 & 349.4 & 347.9 & 349.4 \\
\hline \multicolumn{2}{|c|}{$\begin{array}{l}\text { Means across growing } \\
\text { seasons }\end{array}$} & 341.9 & 341.8 & 343.8 & 332.2 & 344.8 & 340.9 \\
\hline \multicolumn{8}{|c|}{ Means across harvests } \\
\hline \multicolumn{2}{|c|}{ I } & 330.6 & 339.6 & 345.9 & 336.2 & 337.2 & 337.9 \\
\hline \multicolumn{2}{|c|}{ II } & 351.6 & 348.1 & 347.2 & 333.1 & 368.4 & 349.6 \\
\hline \multicolumn{2}{|c|}{ III } & 343.6 & 337.7 & 338.1 & 327.5 & 328.7 & 335.1 \\
\hline
\end{tabular}

$\begin{array}{llll}\text { LSD }_{0.05} \text { for: } & \mathrm{A}=\mathrm{NS}^{*} & \mathrm{~B}=15.3 & \mathrm{C}=\mathrm{NS} \\ & \mathrm{A} / \mathrm{B}=\mathrm{NS} & \mathrm{B} / \mathrm{A}=\mathrm{NS} & \mathrm{A} / \mathrm{C}=\mathrm{NS} \\ & \mathrm{C} / \mathrm{A}=\mathrm{NS} & \mathrm{B} / \mathrm{C}=\mathrm{NS} & \mathrm{C} / \mathrm{B}=\mathrm{NS}\end{array}$

*S - slurry; S +UGmax - slurry + biopreparation UGmax; S + HA - slurry + biopreparation Humus Active; $\mathrm{S}+\mathrm{NPK}$ - slurry + mineral fertilizers NPK

** NS - not significiant

Table 6. The effect of treatments on acid detergent lignin content in Lolium multiflorum dry matter across harvests and growing seasons $\left(\mathrm{g} \mathrm{kg}^{-1}\right)$

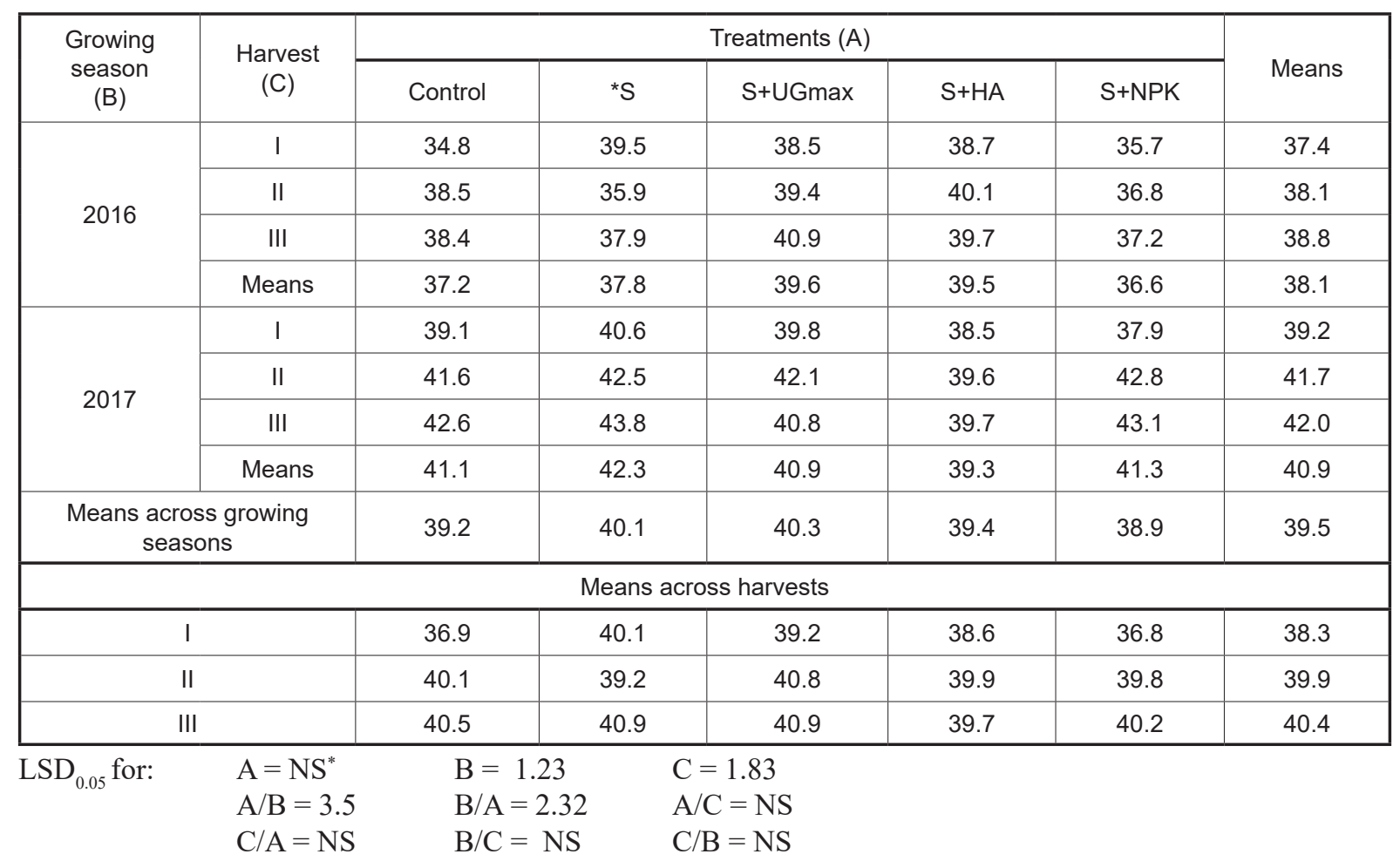

*S - slurry; S +UGmax - slurry + biopreparation UGmax; S + HA - slurry + biopreparation Humus Active; S + NPK - slurry + mineral fertilizers NPK

** NS - not significian 


\section{DISCUSSION}

The content of structural carbohydrates (crude fibre) plays a huge role in animal nutrition. According to Grzelak (2010) the crude fibre content in the grassland forage intended for feeding ruminants should range from 200 to $250 \mathrm{~g} \mathrm{~kg}^{-1} \mathrm{DM}$. The shortage of crude fibre in the feed below 160 the $\mathrm{g} \mathrm{kg}^{-1} \mathrm{DM}$ causes a decrease in the production of animals, while the excessive crude fibre amounts, above $260 \mathrm{~g} \mathrm{~kg}^{-1} \mathrm{DM}$, cause a sense of satiety, but do not cover the animal's nutritional requirements due to the low energy concentration. In the present studies Lolium multiflorum biomass had much higher crude fibre content (on average from 256.2 to $300.4 \mathrm{~g} \mathrm{~kg}^{-1}$ ) than the optimum set by Łuczak and Rogalski (2004). Therefore, it did not meet nutritional requirements of ruminants.

Grzelak (2010) points out that the crude fibre is essential for a proper digestion of feed in the bovine gastrointestinal tract. According to the animal feeding standards, the minimum quantity of the crude fibre in the cattle feed should be $13 \%$, with $18-22 \%$ for dairy cows. The above figures are also confirmed by other authors (Wróbel et al. 2010; Wróbel et al. 2013a, b)

According to Kotlarz et Al. (2010) and Grygierzec (2012) the fibre content in hay is much higher and ranges from 281.1 to $331.8 \mathrm{~g} \mathrm{~kg}^{-1} \mathrm{DM}$. Moreover, Jankowska-Huflejt and Wróbel (2008) in the studies carried out on grassland of organic farms recorded considerably higher (about $300 \mathrm{~g} \mathrm{~kg}^{-1}$ ) crude fibre content in the forage. The analysis of the crude fibre content demonstrated a significant variation depending on the harvest. On average, across years and treatments, the largest crude fibre content in the Lolium multiflorum biomass was found in the third harvest $\left(293.9 \mathrm{~g} \mathrm{~kg}^{-1}\right)$ and the smallest in the first $\left(260.2 \mathrm{~g} \mathrm{~kg}^{-1}\right)$.

The inverse relationship was recorded by Jankowska-Huflejt and Wróbel (2010) with the lowest crude fibre content in the third harvest $\left(261.8 \mathrm{~g} \mathrm{~kg}^{-1} \mathrm{DM}\right)$ and the highest in the second (313.7 $\left.\mathrm{g} \mathrm{kg}^{-1} \mathrm{DM}\right)$. According to Olszewska (2009), the increased crude fibre content in grass is the result of the plant reaction to water scarcity, as confirmed by the studies carried out by Jankowski and Jodełka (2000), who also noticed that the increase in the fibre content can be caused by high temperatures as well. According to Brzóska and Śliwiński (2011), neutral detergent fibre is particularly important for ruminants as it is a source of energy for the rumen microorganisms, gives the forage its structure and is a ballast that fills up the rumen. In addition, the content of the neutral detergent fibre (NDF) in the forage allows the farmer to predict the intake of the feed (Aufrere et al. 2008). The desired content of this parameter in hay for dairy cattle is approximately $400 \mathrm{~g}^{*} \mathrm{~kg}^{-1}$ (Mertens 2012).

In addition, Rodrigues et al. (2008), Salama et al. (2009), Bélanger et al. (2013) and Stejskalova et al. (2013), point out that both the NDF and ADF fractions used in place of the crude fibre or alongside it are important elements in the modern systems of feeding animals, especially cows. The present studies demonstrated that the content of the NDF fraction was not significantly differentiated by the treatments and was in the range of 514.6 to $539.4 \mathrm{~g} \mathrm{~kg}^{-1} \mathrm{DM}$. Thus, it fulfilled the feed requirements provided by Mertens (2012) as well as by Brzóska and Śliwinski (2011).

The content of the NDF fraction in the forage from a permanent meadow recorded by Grzelak and Bocian (2009) was lower and ranged from 411.8 to $501.0 \mathrm{~g} \mathrm{~kg}^{-1} \mathrm{DM}$. In turn, Jankowska-Huflejt and Wróbel (2008) found significantly higher levels of NDF in forage from organic grasslands ranging from 513.5 to $616.1 \mathrm{~g} \mathrm{~kg}^{-1} \mathrm{DM}$

In the present studies, the slurry applied with mineral fertilisers and soil conditioners contributed to a slight increase in the content of the NDF fraction of the grass species. In turn, in the studies conducted by Wróbel et al. (2013) on meadow forage, slurry and manure significantly reduced the content of the NDF fraction.

Another fraction of the crude fibre is the acid detergent fibre (ADF). The optimum content of the acid detergent fibre in forage should range from 190 to $210 \mathrm{~g} \mathrm{~kg}^{-1} \mathrm{DM}$ (Linn and Martin 1989). However, when it is higher, it causes a deterioration in the fodder digestibility. The content of ADF was similar in the meadow hay studied by Grzelak and Bocian (2009) and Grzelak (2010). The results of the present experiment showed no significant effect of the interaction between the slurry and the NPK fertilizers or the slurry and soil conditioners on the ADF content in the grass.

The content of the ADF fraction recorded in the present experiment is much closer to that of Tomic et al. (2012) and is on average in the range of 335.1 in the third harvest to $349.6 \mathrm{~g} \mathrm{~kg}^{-1}$ DM in the second. According to Kotlarz (2010) the content of acid detergent lignin (ADL) can be used as an indicator of the plant lignification process advancement and an increased content 
of this parameter in forage significantly reduces its digestibility. In the present experiment, the content of the acid detergent lignin in the Lolium multiflorum biomass across the growing seasons and treatments was $39.5 \mathrm{~g} \mathrm{~kg}^{-1} \mathrm{DM}$.

The impact of the slurry and its interaction with soil conditioners and its interaction with the NPK fertilizers on the ADL fraction in Lolium multiflorum was negligible and ambiguous. However, the content of the ADL fraction varied across the consecutive harvests of the same growing season. It was at its highest (40.4 $\left.\mathrm{g} \mathrm{kg}^{-1} \mathrm{DM}\right)$ in the third harvest and at its lowest $\left(38.3 \mathrm{~g} \mathrm{~kg}^{-1} \mathrm{DM}\right)$ in the first. Barszczewski et al. (2010) recorded the ADL fraction content in meadow sward ranging from 37.6 to $52.9 \mathrm{~g} \mathrm{~kg}^{-1} \mathrm{DM}$. The larger content of this fraction was in the plants of the second harvest and the lowest in the first and third.

\section{CONCLUSIONS}

The crude fibre content in Lolium multiflorum significantly varied across harvests. The slurry and its interaction with soil conditioners and mineral fertilizers did not have a significant effect on the quantity of this parameter in the harvested biomass, although its content was higher when the plants were treated with the slurry supplemented with soil conditioners.

The content of the NDF fraction was not significantly affected by the experimental factors and was in the range of 514.6 to $539.4 \mathrm{~g} \mathrm{~kg}^{-1} \mathrm{DM}$. The interaction between the slurry, mineral fertilizers and soil conditioners contributed only to a slight increase in the content of the NDF fibre in the grass on the control plot and on that treated with the slurry alone.

The effect of the interaction between the slurry and soil conditioners on the ADF and ADL fibre content in the grass was not reported. However, this content varied significantly across the growing seasons, with unfavourable temperature and rainfall throughout both of them.

\section{Acknowledgements}

The results of the research carried out under research theme No.39/20/B were financed from the science grant granted by the Ministry of Science and Higher Education.

\section{REFERENCES}

1. Aufrere J., Carrere P., Dudilieu M., Baumont R. 2008. Estimation of nutritive value of grasses from semi-natural grasslands by biological, chemical and enzymatic methods. Grasssland Science in Europe, 13, 426-428.

2. Bac S., Koźmiński C., Rojek M. 1993. Agrometeorology, PWN Warsaw, (Poland), 32-33.

3. Barszczewski J., Wróbel B., Jankowska-Huflejt H., Mendra M. 2010. The effect of different methods of fertilisation on meadow sward and silage quality. Scientific Notebooks of the College of Agribusiness in Łomża, (Poland), 46, 7-16.

4. Bélanger G., Virkajarvi P., Duru M., Tremblay G. F., Saarijarvi K. 2013. Herbage nutritive in lessfavoured areas of cool regions. Grassland Sciences in Europe, 18, 57-70.

5. Brzóska F., Śliwiński B. 2011. Quality of roughage for feeding ruminants and methods of its assessment. Part II. Methods for analyzing and assessing the nutritional value of roughage. Zootechnical News, (Poland), XLIX, 4, 57-68.

6. Burns G. A., Gilliland T. J., McGilloway D. A., O’Donovan M., Lewis E., Blount N., O’Kely P. 2010. Using NIRS to predict composition characteristics of Lolium perenne L. cultivars. Advances in Animal Biosciences, 1, 321-321.

7. Grygierzec B. 2012. Content of basic nutrients and fiber fractions in hay from extensively used communities of Alopecuretum pratensis and Holcetum lanati. Grassland in Poland, (Poland) 15, 53-65.

8. Grzelak M. 2010. Production and fodder value of dried from extensively utilized meadows. Science Nature Technologies, (Poland), 1, 1-8.

9. Grzelak M., Bocian T. 2009. Nutritional value of green fodder and hay from ecological meadows, Journal of Research and Applications of Agricultural Engineering, (Poland), 54 (3), 86-90.

10. Jankowska-Huflejt H., Wróbel B. 2010. Assessment of the effect of manure fertilization on the nutritional value of meadow sward and its suitability for ensiling. . Journal of Research and Applications of Agricultural Engineering, (Poland), 55(3), 133-136.

11. Jankowska-Huflejt H., Wróbel B. 2008. Assessment of the suitability of feed from grassland for animal production on tested ecological farms. Journal of Research and Applications of Agricultural Engineering, (Poland) 53(3), 103-108.

12. Jankowski K., Jodełka J. 2000. Analysis of the impact of climatic factors on the yield and nutritional value of four legume-grass mixtures. Science Notebooks in Siedlce. Agriculture, (Poland) 57, 93-101.

13. Kotlarz A., Stankiewicz S., Biel W. 2010. Botanical and chemical composition of hay from a 
semi-natural meadow and its nutritional value for horses. Acta Scientiarum Polonorum, Zootechnica, (Poland), 9 (4), 119-128.

14. Kukułka J., Kozłowski S. 2004. Chemical properties of meadow plants. Ed. Kurpisz S. A., Poznań, (Poland), 80-111.

15. Linn J.G., Martin N.P. 1989. Forage quality test and interpretation. Minnesota Extension Service, University of Minesota, 1-5.

16. Łuczak W., Rogalski M. 2004. Grassland feed for animal nutritions. Grassland. Ed. Kurpisz S.A., Poznań, (Poland), 193-204.

17. Mertens D.R. 2012. Mertens Innovation \& Research LLC, Belleville, WI, Personal Communications.

18. Olszewska, M. 2009. Reaction of meadow fescue (Festuca pratensis Huds.) and timothy (Phleum pratense L.) cultivars grown on organic soil to water deficiency. Acta Scientiarum Polonorum. Agricultura, (Poland), 8(1), 37-46.

19. PTG. (2011). Systematics of Polish soils. Annals of Soil Science, (Poland), 62(3), 128-134.

20. Reddersen B., Fricke T., Wachendorf M. 2012. Influence of NIRS - method on the calibration of N-, ash- and NDF-content of grassland hay and silage. Grassland Sciences in Europe, 17, 385-387.

21. Rodrigues A. M., Andueza D., Picard F., Cecato U., Farruggia A., Baumont R. 2008. Classification of mountain permanent grasslands based on their feed value. Biodiversity and animal feed. EGF, Grassland Sciences in Europe, 13, 501-503.

22. Salama H., Lösche M., Herrmann A., Gierus M.,
Taube F. 2009. Digestibility and fibre fractions of perennial ryegrass (Lolium perenne L.) as affected by cultivar and ploidy level. Biodiversity and animal feed. Grassland Sciences in Europe, 13, 504-506.

23. Skowera B., Puła J. 2004. Extreme pluviothermal conditions in the spring in Poland in 1971-2000. Acta Agrophysica, (Poland),3(1), 171-177.

24. Stejskalova M., Hejcmanová P., Hejcman M. 2013. Forage value of leaf fodder main European broadleaved woody species. Grassland Sciences in Europe, $18,85-87$.

25. Tomic Z., Bijelic Z., Zujovic M., Simic A., Kresovic M., Mandic V., Stanisic N. 2012. The effect of nitrogen fertilization on quality and yield of grass - legume mixtures. Grassland Sciences in Europe, 17, 187-189.

26. Wróbel B., Zielińska K. J., Fabiszewska A. U. 2012. The effect of mineral NPK and organic fertilisation on the content of nutritive components and microbiological quality of the first regrowth of meadow sward. Journal of Research and Applications in Agricultural Engineering, 60 (4), 129-134.

27. Wróbel B., Zielińska K. J., Fabiszewska A. U. 2013a. Evaluation of bacterial inoculation effectiveness in ensilage of meadow sward fertilized with natural fertilizers. Journal of Research and Applications in Agricultural Engineering, 58(4), 233-237.

28. Wróbel B., Zielińska K. J., Fabiszewska A. U. 2013 b. Impact of bovine manure fertilization on the quality of sward and its suitability for ensiling. Problems of Agricultural Engineering,, (Poland), 2(80), 151-164. 